\title{
Oncolytic viruses for cancer immunotherapy
}

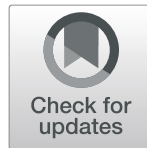

Otto Hemminki ${ }^{1,2,3^{*}}$ (D, João Manuel dos Santos ${ }^{2,4}$ and Akseli Hemminki $2,4,5^{*}$

\begin{abstract}
In this review, we discuss the use of oncolytic viruses in cancer immunotherapy treatments in general, with a particular focus on adenoviruses. These serve as a model to elucidate how versatile viruses are, and how they can be used to complement other cancer therapies to gain optimal patient benefits. Historical reports from over a hundred years suggest treatment efficacy and safety with adenovirus and other oncolytic viruses. This is confirmed in more contemporary patient series and multiple clinical trials. Yet, while the first viruses have already been granted approval from several regulatory authorities, room for improvement remains.

As good safety and tolerability have been seen, the oncolytic virus field has now moved on to increase efficacy in a wide array of approaches. Adding different immunomodulatory transgenes to the viruses is one strategy gaining momentum. Immunostimulatory molecules can thus be produced at the tumor with reduced systemic side effects. On the other hand, preclinical work suggests additive or synergistic effects with conventional treatments such as radiotherapy and chemotherapy. In addition, the newly introduced checkpoint inhibitors and other immunomodulatory drugs could make perfect companions to oncolytic viruses. Especially tumors that seem not to be recognized by the immune system can be made immunogenic by oncolytic viruses. Logically, the combination with checkpoint inhibitors is being evaluated in ongoing trials. Another promising avenue is modulating the tumor microenvironment with oncolytic viruses to allow T cell therapies to work in solid tumors.

Oncolytic viruses could be the next remarkable wave in cancer immunotherapy.
\end{abstract}

Keywords: Adenovirus, Oncolytic, Tumor, Cancer, Immunotherapy, Review, Immunology, Immune system, Immunosupression

\section{Background}

Cancer is becoming a leading cause of death globally. Eighteen million new cancers are diagnosed every year causing almost 10 million deaths (International Agency for Research on Cancer (IARC), 2019). There has been significant progress in the prevention and diagnosis of cancer, but the incidence and mortality are still increasing [1-3]. Conventional therapies, such as surgery,

\footnotetext{
* Correspondence: Otto.hemminki@helsinki.fi; akseli.hemminki@helsinki.fi 'Division of Urologic Oncology, Department of Surgical Oncology, Princess Margaret Cancer Centre, University Health Network and University of Toronto, Toronto, Ontario, Canada

${ }^{2}$ Cancer Gene Therapy Group, Translational Immunology Research Program, University of Helsinki, Helsinki, Finland

Full list of author information is available at the end of the article
}

chemotherapy, hormonal therapies, targeted therapies or radiation therapy, deliver limited durable responses in a great majority of patients with advanced cancers $[4,5]$. Hematological and testicular malignancies are some of the few exceptions where current therapies can be curative even in metastatic cases [6-8].

Cancer is a genetic disease and it represents a range of manifestations. The principles of tumorigenesis are however similar across different tumors and relatively well characterized. In brief, frequent mutations occur during cell divisions or due to exogenous factors such as radiation or other carcinogens. Most of these mutations are corrected by specialized intracellular proteins. If such mechanisms are unsuccessful, mutated cells are generally cleared by apoptosis. 
The vast majority of mutations do not help the cell to gain cancerous properties (passenger mutations). In contrast, driver mutations provide exclusive abilities to tumor cells, such as cell death resistance or metastatic capacity, for example $[9,10]$. Most of these mutated cells are, however, recognized by our immune system and destroyed before clinical detection. Accumulating evidence supports the notion that a dysfunctional immune system is intimately associated with tumor development, progression, and recurrence [11]. Also known as immunosuppression, this phenomenon is actively propagated by cancer cells either directly or through the tumor microenvironment [12]. This understanding has galvanized the interest in the development of immunotherapies, which aims at modifying and activating immune cells to attack cancer cells. The approach is rational as our immune system has been trained to detect, destroy, and memorize non-self patterns. By definition, all cancer cells have multiple mutations causing non-self structures that can potentially be detected by our immune system [9].

The concept of immunotherapy has been acknowledged already for centuries (Table 1). The relationship between microbial infections and spontaneous tumor regressions has been reported several times in the literature [13]. Probably the first evidence was the Ebers papyrus $(1550 \mathrm{BC})$, one of the oldest and most important medical documents of ancient Egypt. The physicians of Egyptian pharaoh Imhotep $(2600 \mathrm{BC})$ used poultice, followed by incision, for the treatment of tumors. This facilitated the development of infections which helped to cause regression of tumors [14]. In 1320, Peregrine Laziozi was affected by cancer of the tibia requiring amputation. Unfortunately, local recurrence and progression were later observed and the tumor finally grew through his skin causing infection. Later, to everyone's astonishment, the tumor disappeared and no relapse was observed. This phenomenon is today known as the St. Peregrine tumor [15].

In the seventeenth and eighteenth centuries, various forms of immunotherapy became widely used. In the eighteenth and nineteenth centuries, septic dressings enclosing ulcerative tumors were sometimes used for cancer treatments. Surgical wounds could be deliberately left open to enable the development of infection as purulent infections were suggested helpful [15]. One of the more detailed case series, indicating several responses, was reported by surgeon William B. Coley. $\mathrm{He}$ treated cancer patients with a bacterial lysate (heat-killed Streptococcus pyogenes and Serratia marcescens), also known as the Coley's toxin [16].

Reports of viruses having therapeutic benefits in cancer started appearing early last century with multiple reports of leukemia patients becoming disease-free after viral infections [17]. Typically, the reported patients were young and the remissions were short-lived lasting for 1 or 2 months [18]. These observations did not go unnoticed by the medical community, who subsequently begun utilizing viruses for the treatment of cancer. Especially during the 1950s and 1960s, multiple wild type viruses (e.g., hepatitis, Epstein-Barr, West Nile, Uganda, dengue, yellow fewer) were used to treat different cancers in hundreds of case series. Results were variable and occasionally poorly documented [17]. However, during this time, it was becoming clear that most wild type viruses lacked efficacy or safety. Some of the more promising results with tolerable side effects were associated with adenoidal-pharyngeal-conjunctival virus [19-22], nowadays known as the adenovirus. For example, in 1956, 30 women with advanced epidermoid carcinoma of the cervix were treated with adenovirus. Intra-arterial, intravenous, and intratumoral administration was used.

Table 1 A timeline including some key steps in development of cancer treatments

\begin{tabular}{|c|c|c|}
\hline \multicolumn{2}{|l|}{ Other cancer treatments* } & \multirow{2}{*}{$\begin{array}{l}\text { Cancer Immunotherapy } \\
\text { Use of poultice (pharaoh Imhotep's physicians) }\end{array}$} \\
\hline Surgery & $2600 \mathrm{BCE}$ & \\
\hline Surgery under ether anesthesia & 1840s CE & Purposeful infection of tumors \\
\hline Radiotherapy & 1890s & Coley's toxins (deactivated bacteria) were injected to tumor \\
\hline $\begin{array}{l}\text { Hormonal therapy (estrogen, castration), } \\
\text { chemotherapy (nitrogen mustard, antifolates) }\end{array}$ & $1900-1940 s$ & Case reports of tumor regression after natural viral infections \\
\hline $\begin{array}{l}\text { Linear accelerator for radiotherapy, } \\
\text { combination chemotherapy }\end{array}$ & $1950 s-1970 s$ & $\begin{array}{l}\text { Hundreds of case series treating cancer with multiple viruses } \\
\text { (e.g., varicella, measles, vaccinia, West Nile, adenovirus, mumps) } \\
\text { BCG adopted in bladder cancer }\end{array}$ \\
\hline Stereotactic radiotherapy, antiestrogens & 1980s & Adoptive T cell transfer, cytokine therapies (e.g., IFN-alpha and IL-2) \\
\hline $\begin{array}{l}\text { Mini-invasive surgery, monoclonal antibodies } \\
\text { (rituximab, trastuzumab) }\end{array}$ & $1990 \mathrm{~s}$ & HD-IL-2 approved by the FDA \\
\hline $\begin{array}{l}\text { Antiangiogenic therapies (bevacizumab), } \\
\text { kinase inhibitors (imatinib) }\end{array}$ & $2000 s$ & First oncolytic adenovirus (H101) approved in China \\
\hline Small molecular inhibitors of various proteins & $2010-$ & $\begin{array}{l}\text { Cellular immunotherapy (sipuleucel-T, TCR, CART), six different } \\
\text { checkpoint inhibitors, oncolytic virus (T-vec) }\end{array}$ \\
\hline
\end{tabular}


Within 10 days, two-thirds of the patients showed necrosis in their tumors and most remarkably, it appeared to be restricted to the cancerous tissue. No safety problems were reported in the use of this wild type virus, suggesting a degree of natural tumor tropism.

Generally, however, virotherapy received little attention and in the 1970s and 1980s, the regulatory aspects of clinical trials with living pathogens became stricter. In turn, chemotherapies, radiation therapy, hormonal therapy, targeted, and antiangiogenic therapies all became mainstream. It took more than three decades before viruses re-emerged, this time as "oncolytic viruses" [23, 24]. An oncolytic virus is a virus that infects and lyses (breaks down) cancer cells but not normal cells. Oncolytic viruses can occur naturally or can be made in the laboratory by modifying natural viruses. These modifications started a new era of less toxic cancer targeted virus-based therapies [25].

Rapid increases in molecular biotechnology techniques provided means to develop novel strategies to harness the immune system for cancer therapy. Currently, a number of approaches, including adoptive cell therapies, monoclonal antibodies, checkpoint inhibitors, and oncolytic viruses constitute the most prominent advancements in cancer treatment due to the capacity to provide durable and effective clinical responses in cancer patients [13]. Conventional treatments such as radiation and chemotherapy treatments also seem to have immunomodulatory effects not recognized before $[26,27]$.

However, it is essential to note that presently therapeutic benefits are restricted to a limited fraction of patients treated with immunotherapy. In particular, solid cancers generally contain a suppressive tumor microenvironment that inhibits $\mathrm{T}$ cell activity and supports tumor progression [28]. In addition, new immunotherapy treatments have led to the occurrence of new immunological adverse events, including cytokine storm and autoimmune events. Considering these challenges, further alterations to these therapeutic strategies are needed. In addition to new immunological treatment strategies, we also need better understanding of individual immune environments to provide maximal patient benefit.

Our aim in this review is to present the current possibilities that oncolytic viruses have to offer. We concentrate on adenoviruses that are the most widely studied virus type. We start by describing general adenovirus biology and describe then some typical modifications that can be used to generate better anti-cancer capabilities. Finally, we describe clinical studies with oncolytic adenoviruses and describe three different types of oncolytic viruses that are already regulatory approved to treat cancer. The aim is to provide a general overview on the field and we acknowledge that many viral constructs, especially with preclinical studies only, are not covered. However, recruiting or completed oncolytic adenovirus trials (source clinicaltrials.org) give a good general view of where the field is today. Finally, we conclude by addressing some future perspectives.

\section{Main text}

Structure, function, and immunogenic cell death: adenovirus as an example

Adenovirus biology has been investigated in detail and it is well understood. Adenoviruses can be used as an example virus when describing oncolytic viruses as a whole. While there are naturally many differences with different viruses, many factors are similar to some degree, however not all viruses are naturally oncolytic.

To date, 57 distinct adenovirus serotypes are described and classified into 7 subgroups: A to G [29, 30]. While adenoviruses trigger common-flu type infections, these represent one of the most versatile platforms for cancer therapy. In particular, serotype 5 (group C) is the most commonly used backbone for oncolytic virus design [29]. Its structure encompasses an icosahedral shaped capsid (composed mainly of hexon, penton, and fiber proteins) surrounding a non-enveloped double-stranded DNA [31]. Adenoviruses have the ability to infect cells independently of their division status.

Infection of tumor cells initiates with the attachment of the virus fiber knob to receptors located on the surface of tumor cells. This interaction is mediated by different receptors depending on the serotype of the virus. For example, serotype 5 adenoviruses bind preferentially to the coxsackie- and adenovirus receptor CXADR [32], while serotype 3 adenoviruses bind desmoglein-2, CD46 or CD80/86 [33-35]. Some of these receptors are frequently found on cancer cells, while unfortunately some, such as CXADR, are downregulated in many advanced tumors [30]. A second interaction between the virus' penton proteins and tumor cell integrins occurs, resulting in virus internalization [36]. Adenoviruses can use also several other receptors as shown in Table 2. A multistep process takes the virus DNA into the nucleus, where transcription of early viral proteins (E1-E4) starts. Following expression of late proteins, thousands of new viral progeny emerges, disrupting the cell membrane after a few days and the newly formed viruses infect new cells, until the immune system eventually stops this process [50].

Although not discovered until the treatment of patients, such cell lysis is a highly immunogenic process [51]. This factor is of pivotal importance considering that most cancers seem to be able to hide from our immune system. Immunogenic cell death reveals multiple tumor-associated antigens for presentation to the immune system via activated mature dendritic cells. High 
Table 2 Entry receptors for adenoviruses [37]

\begin{tabular}{|c|c|c|}
\hline Receptor & Ligand & Reference \\
\hline \multicolumn{3}{|l|}{ Primary receptors } \\
\hline CXADR (coxsackie-adenovirus receptor) & Ad5 knob (and other groups A, C, D, E, and F) & [38] \\
\hline CD46 & Ad3 knob (and other groups B and D) & [39] \\
\hline Desmoglein-2 & Ad3 knob (and other group B) & {$[40,41]$} \\
\hline CD80/CD86 & Ad3 knob (and other group B) & {$[33,37]$} \\
\hline \multicolumn{3}{|l|}{ Other receptors } \\
\hline Cellular integrins & Ad capsid (penton base) or Arg-Gly-Asp (RGD) modifications & [42] \\
\hline Sialic acid & Ad 37, 8, 19a (group D) & [43] \\
\hline MHC-I (major histocompatibility complex class I) & Ad5 & [44] \\
\hline Vascular adhesion molecule 1 (VCAM-1) & Ad5 & [45] \\
\hline Heparan sulfate glycosaminoglycans (HS-GAGs) & Ad5 & [46] \\
\hline Dipalmitoyl phosphatidylcholine (DPPC) & Ad5 hexon & [47] \\
\hline Blood coagulation factor $F(X)$ & Ad 5 hexon & {$[48,49]$} \\
\hline
\end{tabular}

numbers of virus genomes activate immunological danger signaling through damage-associated molecular pattern (DAMP) and pathogen-associated molecular pattern (PAMP) receptors. These processes form a recipe that retargets the adaptive immune system, including cytotoxic CD8+ $\mathrm{T}$ cells and helper $\mathrm{CD} 4+\mathrm{T}$ cells, towards the tumor, thus lifting local immunosuppression [52]. Of note, anti-adenoviral $\mathrm{T}$ cell immunity is polyfunctional rendering increased quality to the overall ongoing antitumor response [53]. Simultaneously, adenovirus infection also mediates activation of natural killer cells further contributing for the antitumor immune response [54]. The generation of antiviral antibodies equally stimulates the response by triggering antibody-dependent cytotoxicity [55] (Fig. 1).

\section{Modern oncolytic viruses}

Today, adenoviruses, herpes viruses, measles viruses, coxsackie viruses, polioviruses, reoviruses, poxviruses, and Newcastle disease viruses, among others, are some of the oncolytic viruses under preclinical and clinical development for cancer therapy [56]. Tumor-preferential replication can be "natural" given the defective viral sensing mechanisms of most cancer cells [57]. Some of the cancer cells also harbor increased expression of viral entry receptors, and some viruses do not appear to need specific receptors for entry [58]. Abnormal function of intracellular signaling pathways such as interferon can be exploited by some viruses [58]. Like many other viruses, adenoviruses are naturally prone to replicate aggressively in tumor cells and, their wild type versions could in theory be used in cancer treatments, as was done in historical series [17, 19-22]. However, better patient outcomes are expected by rational design of viruses rendering them tumor selective ("oncolytic"). In recent years, adenoviruses have been extensively altered to merge high antitumor potency with minimal toxicity [25].

Existing molecular biology techniques allow us to (a) select entry receptors highly expressed on tumors, (b) refine safety by restricting replication to cancer cells, and (c) insert specific therapeutic transgenes for increased efficacy. These approaches are discussed below and summarized in Table 3.

\section{Enhancing tumor tropism}

Effective entry of oncolytic viruses into tumor cells is a prerequisite for subsequent oncolysis. Conversely, low receptor expression can be a limiting factor. To avoid the conundrum of low expression of CXADR on tumors cells, serotype 5 adenoviruses can be modified to contain arginylglycylaspartic acid (RGD) peptides in their fiber knobs. Such modification has been shown useful to increase efficacy and reduce the toxicity of adenoviruses $[59,60]$. Clinical implementation of such modified oncolytic adenoviruses, such as DNX-2401 (an serotype 5 adenovirus with an RGD modification), has shown promising results in a phase I clinical study where $20 \%$ of glioma patients showed durable responses [61].

Likewise, replacement of the serotype 5 fiber knob with one belonging to the serotype 3 has provided substantial improvements in antitumor efficacy, while retaining the appealing systemic kinetics and safety of the ubiquitous serotype $5[62,63]$. Capsid modification (e.g., 5/3 chimerism) allows partial overcoming of preexisting neutralizing antibodies against Ad5 [72]. Of note, the antibody question is complex, and in fact baseline neutralizing antibody titers have not prevented antitumor efficacy in humans [76, 87]. The large amounts of virus that are produced by tumors into the bloodstream 


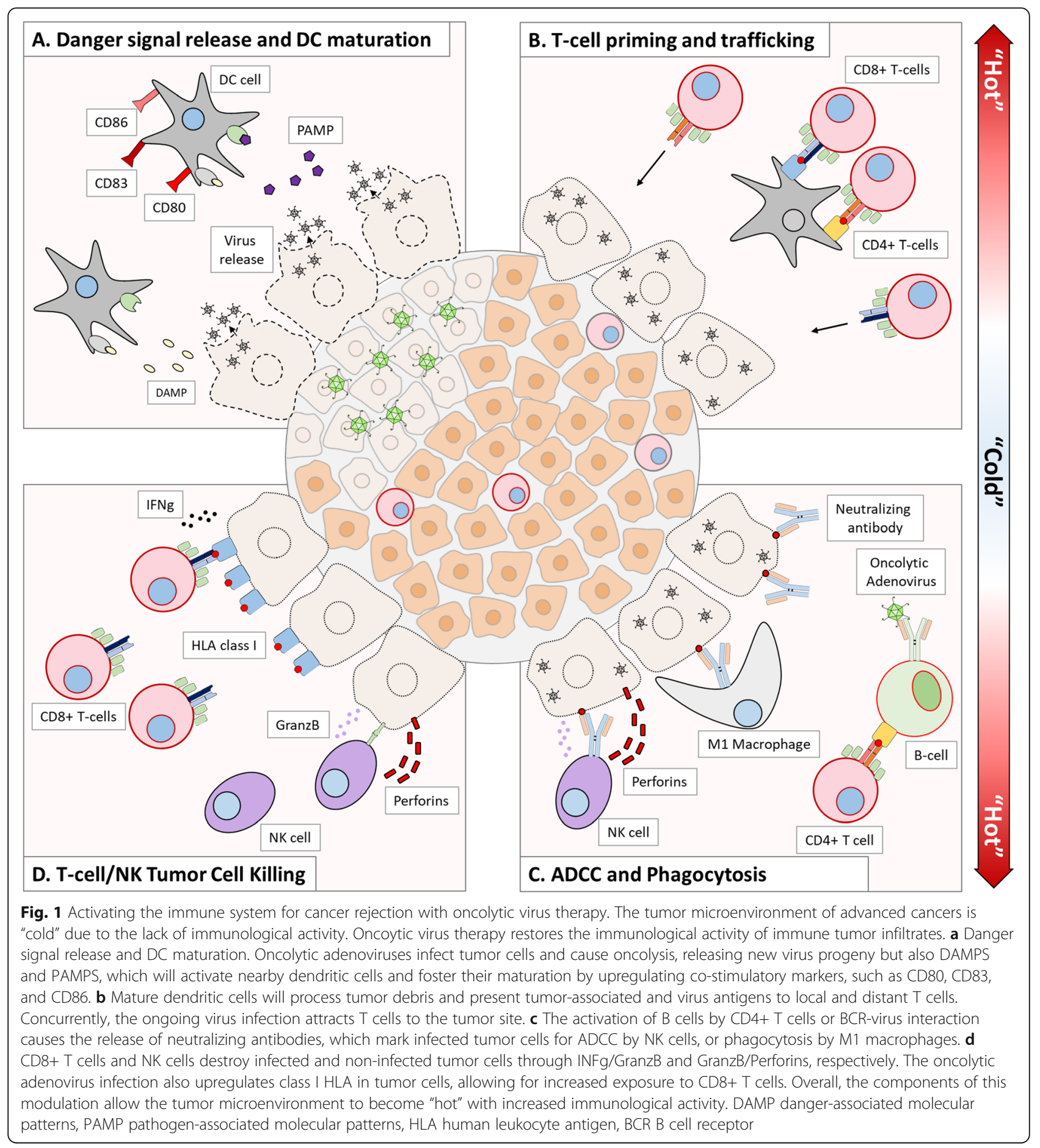

might simply overcome neutralizing antibodies producible into blood. In wild type adenovirus infections, only small amounts of adenovirus enter the blood. Neutralizing antibodies are designed to block such virus, not the huge numbers produced by tumors infected with oncolytic virus. Nevertheless, in epidemiological analysis, lack of antibodies at baseline impacted survival statistically significantly [76], but not in a clinically meaningful manner, as responses and long survival could be seen regardless of baseline antibody titers. Interestingly, sequential intravenous treatments by changing the virus or serotype might make a difference [88].

As expression of the Ad5 receptor CXADR appears limiting for efficacy in the context of advanced tumors, fully serotype 3-based oncolytic adenoviruses have been constructed [64]. This virus enters through non- 
Table 3 Examples of viral modifications in oncolytic adenoviruses

\begin{tabular}{|c|c|}
\hline Modification & Reference \\
\hline \multicolumn{2}{|l|}{ Enhancing tumor tropism } \\
\hline RGD modification & {$[59-61]$} \\
\hline $5 / 3$ chimerism & {$[62,63]$} \\
\hline Fully serotype 3 , Ad3/Ad11p & {$[30,64,65]$} \\
\hline \multicolumn{2}{|l|}{$\begin{array}{l}\text { Safety, restricting replication to } \\
\text { cancer cells }\end{array}$} \\
\hline E1A gene 24-base pair deletion & {$[61,66,67]$} \\
\hline hTERT promoter & {$[64,68]$} \\
\hline p53 promoter & {$[69]$} \\
\hline CEA promoter & {$[70]$} \\
\hline PSA promoter & {$[71]$} \\
\hline E2F promotor & {$[72]$} \\
\hline Cox2l promoter & {$[73]$} \\
\hline \multicolumn{2}{|l|}{ Transgenes, enhancing efficacy } \\
\hline $\begin{array}{l}\text { Cytosine deaminase and } \\
\text { thymidine kinase }\end{array}$ & {$[74]$} \\
\hline $\begin{array}{l}\text { Ganciclovir and/or } \\
\text { 5-fluorocytosine (5-FC) prodrugs }\end{array}$ & {$[75]$} \\
\hline GMCSF & {$[66,67,72,76,77]$} \\
\hline CD40L & {$[78,79]$} \\
\hline hNIS & {$[80]$} \\
\hline TNFalpha and interleukin 2 & NCT04217473 \\
\hline CD40L and 41BBL & NCT03225989 \\
\hline PH20 hyaluronidase & NCT03284268 \\
\hline Anti-CTLA4 & {$[81]$} \\
\hline IL-12 and decorin & {$[82]$} \\
\hline OX40L & {$[83]$} \\
\hline EGFR & {$[84]$} \\
\hline FR-a & {$[85]$} \\
\hline FAP & {$[10]$} \\
\hline CD44v6 & {$[86]$} \\
\hline
\end{tabular}

CXADR-mediated mechanisms including desmoglein 2, which is highly expressed in advanced solid tumors [30, 35, 64, 78]. Good safety and signs of efficacy were seen in patients treated with a fully serotype 3 adenovirus [64]. Furthermore, a direct evolution method [65] was used to generate an Ad3/Ad11p chimeric virus which has been used in multiple trials under the name ColoAd1 [89].

\section{Safety, restricting replication to cancer cells}

To achieve efficient dissemination of input virus and to minimize virus-related adverse events, adenoviruses have been modified to achieve increased tumor selectivity. The strategies employed include transcriptional control of adenovirus early proteins such as the E1A or E1B. An
E1A gene 24-base pair deletion produces a mutated E1A protein which cannot bind to the retinoblastoma protein, thus preventing healthy cells from entering in synthesis ("S") phase. This blocks adenovirus DNA replication in quiescent normal tissues $[61,66]$. In contrast, the replicative potential remains intact in tumor cells because ubiquitous defects in the $\mathrm{p} 16 / \mathrm{Rb}$ pathway ensure that cancer cells permanently stay in synthesis phase [90].

The fact that tumor cells contain several active oncogenes led to the realization that their resulting proteins could be harnessed to control transcription of adenovirus DNA. For example, telomerase activity is a known feature of cancer cells, while activity in healthy cells is minimal [30, 91]. Therefore, adenovirus replication has been successfully placed under the control of a human telomerase reverse transcriptase (hTERT) promoter showing antitumor efficacy in advanced cancers $[64,68]$. Similarly, p53 [69], carcinoembryonic antigen (CEA) [70] and prostate-specific antigen (PSA) [71] have been utilized to control expression of early adenovirus proteins. Due to $\mathrm{Rb} / \mathrm{p} 16$ pathway defects, cancer cells feature high levels of intracellular free E2F, which can be used for tumor specificity when the E2F promotor is inserted to control viral replication [72].

\section{Transgenes, enhancing efficacy}

The nature of viruses allows them to hijack the host cell to produce virus proteins. This allows therapeutic exploitation with the insertion of therapeutic transgenes into the adenovirus genome. Before the recognition of oncolytic adenoviruses as immunotherapy, one of the most common modifications was the insertion of the cytosine deaminase and herpes simplex-derived thymidine kinase [74]. The combined administration of oncolytic adenoviruses with ganciclovir and/or 5fluorocytosine (5-FC) prodrugs caused tumor cell death due to their conversion into cytotoxic compounds by transduced tumor cells [75].

More recently, the increased recognition of the immune system as an important component in the efficacy of oncolytic viruses led researchers to perceive oncolytic adenoviruses as potent vehicles for immune factors. Adding a granulocyte macrophage colony stimulating factor (GMCSF) cytokine transgene into the adenoviral genome is a commonly used modification. In this approach, virus replication is accompanied by GMCSF production, which results in the recruitment and maturation of dendritic cells (DCs), and subsequent priming of $\mathrm{T}$ cells with tumor-associated antigens released by oncolysis [92]. CGTG-102 (previously Ad5/3-D24-GMCSF, currently ONCOS-102), is an oncolytic adenovirus expressing GMCSF. Patient data confirms this notion, with reported increases in peripheral levels of $\mathrm{T}$ cells against 
tumor-associated antigens [66]. These finding suggest dendritic cell priming in humans as predicted by the established mechanism of action of GMCSF [93]. The increased CD8+ T cell infiltration found in tumor biopsies after treatment of advanced cancer patients with ONCOS-102 underlines the immunological potency of this approach [94]. However, the pleiotropic effects of GMCSF may endanger antitumor immunity as the cytokine can unwantedly stimulate myeloid-derived suppressor cells (MDSCs) and tumor-associated macrophages (TAMs), both known to inhibit $\mathrm{T}$ cell and natural killer cell (NK) activity [95]. However, emerging human data suggests that GMCSF producing viruses might be safe and effective [76, 77].

Beyond GMCSF, combined expression of IL-12 and decorin in an oncolytic adenovirus allowed the recovery of antitumor immunity in a poorly immunogenic murine breast cancer model, via cytotoxic $\mathrm{T}$ cell infiltration and transforming growth factor beta (TGFb) reduction [82]. Coexpression of CD40L and 4-1BBL by an oncolytic adenovirus has also shown promising results, due to its ability to promote the destruction of pancreatic tumors, through repolarization of the tumor microenvironment. Such polarization enabled release of $\mathrm{T}$ cell attractants and immune stimulatory cytokines, allowing potent antitumor $\mathrm{T}$ cell responses [96]. Production of OX40L mediated by an oncolytic adenovirus (d24-RGDOX) promoted increased tumor control via highly functional effector $\mathrm{T}$ cells and epitope spreading [83].

Also, antibodies can be inserted as transgenes to enhance the efficacy of oncolytic virotherapy. For example, anti-CTLA4, a checkpoint inhibitor, has been successfully inserted in an oncolytic adenovirus platform. Its usage in murine models and ex vivo cultures of cancer patient peripheral blood mononuclear cells (PBMCs) resulted in increased antitumor activity of $\mathrm{T}$ cells [81]. More recently, dual targeted antibodies targeting $\mathrm{T}$ cells and cancer-specific cell surface antigens such as epidermal growth factor receptor (EGFR) [84], FR-a [85], familial adenomatous polyposis (FAP) [10] and CD44v6 [86], have demonstrated promising preclinical results [84].

Moreover, also other approaches have been studied. These include arming with fusogenic molecules, antibodies, $\mathrm{T}$ cell engagers, and ion channels capable of concentrating radioiodine. While in these cases, the transgenes are not necessarily immunologically active, and the oncolytic platform results in immunostimulation. It is important to note that clinical data suggests that oncolytic adenovirus single-agent efficacy has often been somewhat limited. Several barriers that affect oncolytic adenovirus therapies have been suggested. These include antiviral interferons, which can be produced by the tumor stroma even if the cancer cells themselves lack such ability [50]. Other reasons include stromal barriers, hypoxia, hyperbaric, necrotic, and acidic areas [97, 98]. However, some of these hurdles have been addressed in redesigned adenoviruses conditionally replicating in response to hypoxic factors or acidic tumor microenvironments [99].

Alternatively, oncolytic adenoviruses have been armed with hyaluronidase [100], an enzyme that degrades hyaluronic acid which hampers virus dissemination. Notably, treatment of a number of preclinical in vivo tumor models allowed increased antitumor efficacy. Neutralizing antibodies remain a concern for oncolytic immunotherapies. However, the use of bispecific adapters to retarget antiviral neutralizing antibodies can offer an attractive approach to increase the effectiveness of oncolytic adenovirus therapy [101]. The coating of oncolytic adenoviruses with tumor derivatives has been reported to allow for successful delivery of particles into the tumor with potent antitumor responses [102].

\section{Advanced Therapy Access Program (ATAP)}

Between 2007 and 2012, 290 advanced cancer patients were treated with 10 different oncolytic viruses (Table 4) totaling 821 treatments. A long-term follow-up of these patients has been published [5]. Treatments were given in the context of an individualized treatment program under the EU Advanced Therapies directive [5]. While many objective responses were seen, no definite conclusions regarding overall survival benefit can be drawn as no reliable control group was available. However, some case-control analyses that were performed suggest survival benefit [88].

While taking into account the limitations of nonrandomized data, some interesting findings emerged $[5,51$, $64,66,80,88,92,103,104,106]$. One of the most important observations was that all of the administered viruses appeared quite safe in patients with advanced cancer. Good tolerability was seen across different serotype viruses, including various capsid modifications, and different immunological arming devices (i.e., GMCSF or CD40L). Concomitant low-dose cyclophosphamide and temozolomide were also well tolerated [107]. The former was used to reduce regulatory $\mathrm{T}$ cells. The latter aimed at increased induction of autophagy in infected cancer cells, as this appears to be an important mediator of oncolytic cell death. Moreover, virus replication could be increased by concomitant calcium channel blockage [108]. No treatment-related patient deaths were observed [63]. Typical flu-like symptoms, such as fever and fatigue, were observed in most patients a few days after treatment. These findings were confirmed in multiple subsequent clinical trials [61, 94, 109]. Flu-like symptoms and fever could be effectively reduced with acetaminophen (paracetamol). 
Table 4 Viruses used in ATAP

\begin{tabular}{|c|c|c|c|c|}
\hline & Serotype & Main target receptor & Tumor specificity & Arming \\
\hline Ad5-D24-GMCSF [92] & 5 & Coxsackie virus and adenovirus receptor & 24 bp deletion in E1 $A^{1)}$ & GMCSF \\
\hline Ad5-RGD-D24 [103] & 5 & Alpha-v-beta integrins & 24 bp deletion in $\mathrm{E} \mathrm{A}^{1)}$ & No \\
\hline Ad5-RGD-D24-GMCSF [103] & 5 & Alpha-v-beta integrins & 24 bp deletion in $\mathrm{E} \mathrm{A}^{1)}$ & GMCSF \\
\hline ICOVIR-7 [104] & 5 & Alpha-v-beta integrins & E2F1 promoter and 24 bp deletion in E1 $A^{1)}$ & No \\
\hline Ad5/3-Cox2L-D24 [73] & 5 & Desmoglein-2 & Cox $2 \mathrm{~L}$ promoter and $24 \mathrm{bp}$ deletion in $\mathrm{E} 1 \mathrm{~A}^{1)}$ & No \\
\hline Ad5/3-D24-GMCSF [88]* & 5 & Desmoglein-2 & 24 bp deletion in $\mathrm{E} \mathrm{A}^{1)}$ & GMCSF \\
\hline Ad5/3-hTERT-hCD40L [73] & 5 & Desmoglein-2 & hTERT promoter ${ }^{2)}$ & CD40L \\
\hline Ad5/3-E2F1-D24-GMCSF [105] & 5 & Desmoglein-2 & E2F1 promoter and 24 bp deletion in E1 ${ }^{1)}$ & GMCSF \\
\hline Ad5/3-D24-hNIS [80] & 5 & Desmoglein-2 & 24 bp deletion in $E 1 A^{1)}$ & hNIS \\
\hline Ad3-hTERT-E1A [64] & 3 & Desmoglein-2 & hTERT promoter ${ }^{2)}$ & No \\
\hline
\end{tabular}

${ }^{*}$ Ad5/3-D24-GMCSF, also known as CGTG-102, and later renamed ONCOS-102, has been subsequently used in several phase 1 and phase 2 clinical trials (www.targovax.com)

${ }^{1)}$ Replication in cells with a deficient Rb/p16 pathway (a hallmark of cancer)

${ }^{2)}$ Replication in cells with active telomerase (a hallmark of cancer)

\section{Systemic delivery of oncolytic virus}

Biodistribution studies done with adenoviruses in rodents are unreliable as most animals lack entry receptors or their organ distribution is different from humans. From ATAP patients, we have been able to collect important information about virus biodistribution in humans [63]. Many humans have neutralizing antibodies against different adenovirus serotypes, although often at low baseline titer [64]. However, as hundreds of billions of viruses are given in a typical treatment, pre-existing antibodies may be unable to completely block intravenous delivery. In subsequent intravenous treatments with the same serotype, the situation is more unclear, which is one of the reasons intratumoral delivery is commonly used with oncolytic viruses. Of note, it has been proposed that antiviral immunity helps generate antitumor immunity [66].

It has been established in humans that adenovirus is able to travel through blood to metastases despite neutralizing antibodies [63]. For some viruses, the mechanism appears to relate to binding to blood cells [110]. Interestingly, adenoviruses in blood (qPCR data) were most often found from blood clots, while some patients had significant amount of virus in the serum compartment [64]. Also cancer patient's antibody response varied [64]. Treatment responses or long survival are seen regardless of neutralizing antibody titers, although it should be noted that most patients were treated intratumorally [76].

Interestingly, we treated seven patients with the serotype 3 adenovirus using only intravenous administration. Signs suggesting virus replication were seen, including prolonged and/or rising virus titers in the blood. This was seen also with patients who had pre-existing antibodies against the virus. Also, 5 of the 6 evaluable patients showed signs of possible benefit. This data indicates that viruses might be able to enter tumors also via the intravenous route [64]. This was later confirmed in an autopsy study where non-injected tumors were shown to have oncolytic adenovirus [63].

\section{Viruses that have already received regulatory approval for the treatment of cancer}

From a clinical standpoint, the use of viruses for cancer treatment in the modern era is in its infancy. Initially, wild type viruses were used, but this approach could result in adverse events caused by virus replication in normal tissues. Nevertheless, Rigvir (an ECHO-7 virus) [111], an oncolytic picornavirus with some innate tumor selectivity, was the first approved oncolytic virotherapy product for cancer approved 2004 in Latvia and later in a few other countries. The second oncolytic virus was rationally designed for tumor selectivity. Named H101 (Oncorine), this adenovirus has been used in China since 2005 for the treatments of solid tumors [112]. Of note, both of these viruses lack arming devices.

The acknowledgement that repurposing the immune system to exert antitumor functions could provide a promising approach to treat cancer enabled scientists to employ the immunological capabilities of oncolytic viruses [113]. For example, the addition of immunological transgenes such as the GMCSF has been a popular approach. Talimogene laherparepvec (also known as T-vec, Imlygic $^{\circ}$ ) is a herpes simplex-1 virus encoding for GMCSF, and was one of the first oncolytic viruses designed to provide an immunological boost. Its clinical application eventually led to a randomized phase III clinical trial (OPTiM). In this trial stage IIIB/C and IV metastatic, unresectable melanoma patients receiving intratumoral T-vec had a $19.3 \%$ durable response rate of which more than $80 \%$ were complete responses [114]. The fact that subcutaneous administration of GM-CSF 
offered inferior efficacy (1.4\% durable response rate, $0.7 \%$ complete response) led to approval by the Food and Drug Administration (FDA) in 2015, followed by European Medicines Agency (EMA) [114].

This landmark approval in Western countries encouraged optimism in the medical community to continue developing and improving oncolytic viruses for cancer therapy, including adenoviruses. Later, in a similar patient population, pembrolizumab was combined with the virus leading to responses in $62 \%$ of the patients, of which $33 \%$ were complete. As expected, a high presence of cytotoxic $\mathrm{T}$ cell infiltration was observed in the tumors following treatment [115]. A recent phase II clinical trial in advanced melanoma patients demonstrated that $\mathrm{T}$-vec increased the response rate of ipilimumab as compared to ipilimumab alone (38\% vs $18 \%$, respectively) [116]. Of note, and in contrast to combinations of checkpoint inhibitors [117], adverse events were not compounded. This suggests that oncolytic viruses can be combined with checkpoint inhibition without a problematic decrease in safety.

\section{Oncolytic adenovirus trials}

At the time of writing this review (March 2020), we did a search on clinicaltrials.org, resulting in 101 trial results. Limiting the search to "oncolytic adenovirus" phases I-II trials, we came up with 41 results; of these, 10 were completed and 15 recruiting. Sixteen different oncolytic viruses were used in these completed or recruiting trials. No active phase III clinical trials were found. Interestingly, 6 out of the 16 viruses have been posted recently, during 2019-2020, indicating growing interest and available funding for oncolytic adenovirus trials (Table 5).

\section{Use of oncolytic viruses in hematologic malignancies}

Observations of hematological cancer regressions following virus infection were seen early last century $[17,18]$. Of note, response evaluation was possible for hematological malignancies, by microscopy and cell counting, while this was not true for most solid tumors at the time. This might have caused overrepresentation of hematological cancer in early literature, due to observational bias. However, it cannot be denied that many reports suggested regression of hematological tumors after viral infections. As such, there is strong rationale to believe that oncolytic viruses could be used also in hematological malignancies. However, not all viruses are suitable for treatment of blood cell tumors. For example, adenovirus does not appear to be able to lyse white blood cells [118].

According to recent publications, growing interest towards oncolytic viruses is present also in the hematological field, as several viruses are being studied in preclinical settings [119]. However, only a few trials have been published [120]. A search from clinicaltrials. gov did not reveal any results for trials on "hematologic neoplasm" and "oncolytic viruses" (March 2020). However, a search for "multiple myeloma" and "oncolytic viruses" found two studies.

To conclude, to date, there have been few trials with oncolytic viruses in hematological cancers. Some noteworthy efforts include early phase trials with reovirus [121], measles [122], and vesicular stomatitis virus (VSV) in multiple myeloma [120]. The currently recruiting VSV trial (NCT03017820) also includes patients with relapsed acute myeloid leukemia and $\mathrm{T}$ cell lymphoma. No hematological trials with oncolytic adenovirus were found.

\section{Limitations and newer strategies to improve efficacy of oncolytic viruses}

Arming with immunostimulatory cytokines has been one popular method to generate immunological synergy with the effects of oncolysis. Clinical benefit of this approach was seen in the phase III OPTiM trial where 1 in 6 patients achieved complete responses with the oncolytic virus talimogene laherparepvec. The median duration of these complete responses in the virus group was not reached and 8 out of 9 patients survived over 5 years [114].

Combining oncolytic viruses with $\mathrm{T}$ cell activating checkpoint inhibition can improve antitumor efficacy of oncolytic adenovirus therapy. Especially tumors with low amount of immunological cells-"cold tumors"-can be efficiently immune activated by oncolytic adenoviruses. This makes tumors "hot" and promotes the effects of checkpoint inhibitors [94, 123]. Clinical proof-ofconcept for the efficacy of combining oncolytic viruses with checkpoint inhibitors has been presented [116, 124]. In a randomized phase II study $(n=198)$ a checkpoint inhibitor (ipilimumab) was combined with the oncolytic virus talimogene laherparepvec, showing objective responses in $39 \%$ of the patients, compared to $18 \%$ in the checkpoint inhibitor-only arm [116, 125].

In addition to melanoma, recent publications suggest clinical activity also in other cancers such as metastatic sarcoma where the same combination resulted in a $30 \%$ objective response rate in a single-arm trial [126]. Furthermore, the safety profile of these treatments has been good and oncolytic viruses do not seem to increase the rate of serious adverse events.

Although these combinations seem to yield increased potency and long-term benefits to some patients, not all benefit, and there is clearly a role for further improvement. Combining chemotherapy or radiation therapy in a rational way to improve treatment benefits, and even these conventional therapies seem to have an 
Table 5 Sixteen oncolytic adenoviruses used in phase I-II trials that have been completed or recruiting (Mar-2020 clinicaltrials.org).

\begin{tabular}{|c|c|c|c|c|c|}
\hline $\begin{array}{l}\text { First } \\
\text { posted }\end{array}$ & $\begin{array}{l}\text { Last } \\
\text { update }\end{array}$ & $\begin{array}{l}\text { Oncolytic } \\
\text { adenovirus } \\
\text { (transgene) }\end{array}$ & Study title(s) & Indication(s) & NCT\# identifier \\
\hline 2012 & 2019 & $\begin{array}{l}\text { ONCOS-102 } \\
\text { (GMCSF) }\end{array}$ & $\begin{array}{l}\text { Completed: ONCOS-102 (Previously CGTG-102) for Therapy of Advanced } \\
\text { Cancers } \\
\text { Recruiting: (1) A Pilot Study of Sequential ONCOS-102, an Engineered } \\
\text { Oncolytic Adenovirus Expressing GMCSF, and Pembrolizumab in Patients } \\
\text { With Advanced or Unresectable Melanoma Progressing After Pro- } \\
\text { grammed Cell Death Protein } 1 \text { (PD1) Blockade (2) A Phase I/II, Safety } \\
\text { Clinical Trial of DCVAC/PCa and ONCOS-102 in Men With Metastatic } \\
\text { Castration-resistant Prostate Cancer }\end{array}$ & $\begin{array}{l}\text { Solid tumors, } \\
\text { melanoma, and } \\
\text { prostate cancer }\end{array}$ & $\begin{array}{l}\text { NCT03003676, } \\
\text { NCT03514836 }\end{array}$ \\
\hline 2012 & 2015 & Delta-24-rgd & $\begin{array}{l}\text { Completed: Safety Study of Replication-competent Adenovirus (Delta- } \\
\text { 24-rgd) in Patients With Recurrent Glioblastoma }\end{array}$ & Glioblastoma & NCT01582516 \\
\hline 2013 & 2020 & DNX-2401 ${ }^{\mathrm{b}}$ & $\begin{array}{l}\text { Completed: (1) Oncolytic Adenovirus, DNX-2401, for Naive Diffuse Intrin- } \\
\text { sic Pontine Gliomas (2) DNX-2401 With Interferon Gamma (IFN- }- \text { ) for Re- } \\
\text { current Glioblastoma or Gliosarcoma Brain Tumors (TARGET-I) (3) Virus } \\
\text { DNX2401 and Temozolomide in Recurrent Glioblastoma (D24GBM) } \\
\text { Recruiting: Oncolytic Adenovirus DNX-2401 in Treating Patients With Re- } \\
\text { current High-Grade Glioma }\end{array}$ & Gliomas & $\begin{array}{l}\text { NCT03178032, } \\
\text { NCT02197169, } \\
\text { NCT01956734, } \\
\text { NCT03896568 }\end{array}$ \\
\hline 2013 & 2016 & CELYVIR & $\begin{array}{l}\text { Completed: Safety and Efficacy of Repeated Infusion of CELYVIR in } \\
\text { Children and Adults With Metastatic and Refractory Tumors. }\end{array}$ & Solid tumors & NCT01844661 \\
\hline 2013 & 2017 & ICOVIR-5 & $\begin{array}{l}\text { Completed: Phase I Endovenous Administration of Oncolytic Adenovirus } \\
\text { ICOVIR-5 in Patients With Advanced or Metastatic Melanoma }\end{array}$ & Melanoma & NCT01864759 \\
\hline 2014 & 2019 & $\begin{array}{l}\text { VCN-01 (PH20 } \\
\text { hyaluronidase) }\end{array}$ & $\begin{array}{l}\text { Completed: A phase I Dose Escalation Study of Intratumoral VCN-01 In- } \\
\text { jections With Gemcitabine and Abraxane in Patients With Advanced } \\
\text { Pancreatic Cancer } \\
\text { Recruiting: Safety, Tolerability, and Efficacy of VCN-01 With Durvalumab } \\
\text { in R/M Head and Neck Squamous Cell Carcinoma }\end{array}$ & $\begin{array}{l}\text { Pancreatic cancer } \\
\text { and head and neck }\end{array}$ & $\begin{array}{l}\text { NCT03284268, } \\
\text { NCT03799744 }\end{array}$ \\
\hline 2014 & 2020 & ColoAd $1^{c}$ & $\begin{array}{l}\text { Completed: Mechanism of Action Trial of ColoAd1 (MOA) } \\
\text { Recruiting: Chemoradiation With Enadenotucirev as a Radiosensitiser in } \\
\text { Locally Advanced Rectal Cancer (CEDAR) }\end{array}$ & $\begin{array}{l}\text { Colon, non-small cell } \\
\text { lung, bladder, and } \\
\text { renal cell }\end{array}$ & NCT02053220 \\
\hline 2015 & 2019 & $\begin{array}{l}\text { CG0070 } \\
\text { (GMCSF) }\end{array}$ & $\begin{array}{l}\text { Completed: Safety and Efficacy of CG0070 Oncolytic Virus Regimen for } \\
\text { High Grade NMIBC After BCG Failure (BOND2) }\end{array}$ & $\begin{array}{l}\text { Superficial bladder } \\
\text { cancer }\end{array}$ & NCT02365818 \\
\hline 2020 & 2020 & $\begin{array}{l}\text { TILT-123 } \\
\text { (TNFalpha and } \\
\text { IL-2) }\end{array}$ & $\begin{array}{l}\text { Recruiting: TNFalpha and Interleukin } 2 \text { Coding Oncolytic Adenovirus } \\
\text { TILT-123 During TIL Treatment of Advanced Melanoma }\end{array}$ & Melanoma & NCT04217473 \\
\hline 2016 & 2020 & $\begin{array}{l}\text { LOAd703 } \\
\text { (CD40L and } \\
\text { 41BBL) }\end{array}$ & $\begin{array}{l}\text { Recruiting: (1) Trial Investigating an Immunostimulatory Oncolytic } \\
\text { Adenovirus for Cancer (2) LOAd703 Oncolytic Virus Therapy for } \\
\text { Pancreatic Cancer (3) A Phase I/II Trial Investigating LOAd703 in } \\
\text { Combination With Atezolizumab in Malignant Melanoma }\end{array}$ & $\begin{array}{l}\text { Pancreatic, ovarian, } \\
\text { biliary, colorectal, and } \\
\text { melanoma }\end{array}$ & $\begin{array}{l}\text { NCT03225989, } \\
\text { NCT02705196, } \\
\text { NCT04123470 }\end{array}$ \\
\hline 2019 & 2020 & ORCA-010 & $\begin{array}{l}\text { Recruiting: First in Man Clinical Study to Evaluate Safety and Tolerability } \\
\text { of an Oncolytic Adenovirus in Prostate Cancer Patients. }\end{array}$ & Prostate cancer & NCT04097002 \\
\hline 2017 & 2017 & $\begin{array}{l}\text { Ad5-yCD/ } \\
\text { mutTKSR39rep- } \\
\text { hIL12 (IL-12) }\end{array}$ & $\begin{array}{l}\text { Recruiting: Phase } 1 \text { Trial of Interleukin } 12 \text { Gene Therapy for Metastatic } \\
\text { Pancreatic Cancer }\end{array}$ & Pancreatic cancer & NCT03281382 \\
\hline 2017 & 2019 & $\begin{array}{l}\text { NSC-CRAd- } \\
\text { Survivin-pk7 }\end{array}$ & $\begin{array}{l}\text { Recruiting: Neural Stem Cell Based Virotherapy of Newly Diagnosed } \\
\text { Malignant Glioma (neural stem cells loaded with NSC-CRAd-Survivin- } \\
\text { pk7) }\end{array}$ & Glioma & NCT03072134 \\
\hline 2019 & 2020 & $\begin{array}{l}\text { NG-641 (CXCL9/ } \\
\text { CXCL10/IFNa) }\end{array}$ & $\begin{array}{l}\text { Recruiting: First in Human Study With NG-641, an Oncolytic Transgene } \\
\text { Expressing Adenoviral Vector } \\
\text { FAP-TAC antibody together with an immune enhancer module (CXCL9/ } \\
\text { CXCL10/FNa). }\end{array}$ & Epithelial tumors & NCT04053283 \\
\hline 2016 & 2019 & $\begin{array}{l}\text { ADV/HSV-tk } \\
\text { (HSV-tk) }\end{array}$ & $\begin{array}{l}\text { Recruiting: SBRT and Oncolytic Virus Therapy Before Pembrolizumab for } \\
\text { Metastatic TNBC and NSCLC (STOMP) }\end{array}$ & Breast and lung & NCT03004183 \\
\hline 2019 & 2020 & $\begin{array}{l}\text { NG-350A (anti- } \\
\text { CD40 ab) }\end{array}$ & $\begin{array}{l}\text { Recruiting: First in Human Study of NG-350A (an Oncolytic Adenoviral } \\
\text { Vector Which Expresses an Anti-CD40 Antibody) (FORTITUDE) }\end{array}$ & Epithelial tumors & NCT03852511 \\
\hline
\end{tabular}

${ }^{\mathrm{a} O N C O S-102}$ was previously used in our ATAP treatment series as Ad5/3-D24-GMCSF and CGTG-102 [88]

bPreviously known as Delta-24-rgd

cAlso knowns as enadenotucirev

${ }^{\mathrm{d}}$ TILT-123 is a double-armed virus designed for activation of T cells. It was designed based on human data from ATAP 
immunological component [27, 127]. However, clear clinical proof in support of this approach is currently limited.

Combining other therapies such as adoptive cell therapy or targeted therapies might also result in better treatments. However, we are still lacking much information about the immune effects in individual tumors. This insufficiency of knowledge makes it hard to understand which patients would benefit most of what kind of treatment combinations. This could be the greatest challenge in the field at the moment. Classic trial design is not well suited for understanding mechanisms on an individual tumor and patient level.

\section{TILT-123 studies}

An ideal cancer treatment should be so good that most patients would clearly benefit while side effects should be tolerable. Our own contribution to this quest is a novel oncolytic adenovirus, designed specifically with $\mathrm{T}$ cells in mind. Ad5/3-E2F-D24-hTNFa-IRES-hIL2 (TILT123) is based on the well understood and safe adenovirus serotype 5 , but its fiber knob has been changed to a serotype $3 \mathrm{knob}$ for enhanced penetrance to tumor cells [128]. The replication of the virus is strictly limited to cancer cells by dual control (E2F promoter and D24 deletion) and the potency of the virus is optimized by two transgenes, which were selected in a data-driven manner $[95,129]$. Chimeric $5 / 3$ adenoviruses also represent the best native $\mathrm{T}$ cell stimulator, among clinically relevant oncolytic adenoviruses [130].

The combination that emerged as the best approach for recruiting and activating $\mathrm{T}$ cells was interleukin-2 (IL-2) and tumor necrosis factor alpha (TNFa) [129]. IL2 is required for $\mathrm{T}$ cell growth and survival and TNFa is a potent inducer of $\mathrm{T}$ cell trafficking and tumor apoptosis [129, 131-133]. In preclinical models, administration of cytokine-coding adenoviruses increased the antitumor efficacy of three forms of adoptive $\mathrm{T}$ cell therapy: T cell receptor (TCR)-engineered T cells [129], CAR T cell therapy [134], and tumor-infiltrating lymphocyte (TIL) therapy $[128,135]$.

This outcome resulted from the following: (1) improved infiltration of transferred cells induced by TNFa, (2) improved activity of cytotoxic T cells induced by IL2 , and (3) overall decrease of immune suppressive subsets including regulatory $\mathrm{T}$ cells (Tregs), MDSCs, and M2 macrophages in the tumor microenvironment [129]. Hamsters bearing pancreatic tumors treated with TILT123 showed signs of improved antitumor efficacy as compared to animals receiving TIL therapy or TILT-123 alone [128]. Combination of IL-2 and TNFa coding adenoviruses and anti-PD-1 therapy also fostered long-term $100 \%$ survival in preclinical models bearing a melanoma tumor model [136].
Further studies with the virus demonstrated abscopal effect in non-injected tumors, showing the systemic nature of the immune response generated by local treatment [128]. Moreover, TILT-123 therapy in TIL-treated animals demonstrated protective immunity towards tumor re-challenge [128]. Importantly, this data demonstrates the potential of TILT-123 to fine-tune and overcome challenges of $\mathrm{T}$ cell-based adoptive cell therapy. The first trial with this advanced oncolytic adenovirus is now ongoing (NCT04217473).

\section{Conclusions}

In summary, while preclinical data for oncolytic adenoviruses is impressive and clinical data have shown efficacy, more potent treatment strategies are needed to achieve long-term tumor control in patients. Thus, it is logical that several approaches are being utilized for improving the efficacy of oncolytic viruses. Hopefully, the efforts of the scientific and medical communities during multiple decades will lead to better treatment options in the near future. Better understanding of individual patient-tumor immune status will likely emerge and we will be able to treat advanced cancer patients better. It appears that oncolytic viruses will be part of future multimodality approaches. New treatments are urgently needed to help the 10 million cancer patients that are dying each year.

\begin{abstract}
Abbreviations
5-FC: 5-fluorocytosine; ADCC: Antibody-dependent cell-mediated cytotoxicity; ATAP: Advancer Therapy Access Program; BCG: Bacillus Calmette-Guérin; CAR: Chimeric antigen receptor; CART: Chimeric antigen receptor T cells; CEA: Carcinoembryonic antigen; CXADR: Coxsackie- and adenovirus receptor; DAMP: Damage-associated molecular pattern; DCs: |Dendritic cells; DNA: Deoxyribonucleic acid; EGFR: Epidermal growth factor receptor; EMA: European Medicines Agency; FAP: Familial adenomatous polyposis; FDA: Food and Drug Administration; GMCSF: Granulocyte macrophage colony stimulating factor; hTERT: Human telomerase reverse transcriptase; IFN: Interferon; IL-2: Interleukin-2; MDSCs: Myeloid-derived suppressor cells; NK: Natural killer cells; PAMP: Pathogen-associated molecular pattern; PBMCs: Peripheral blood mononuclear cells; PSA: Prostate-specific antigen; RGD: Arginylglycylaspartic acid; TAMs: Tumor-associated macrophages; TCR: T cell receptor; TGFb: Transforming growth factor beta; TIL: Tumor-infiltrating lymphocyte; TNFa: Tumor necrosis factor alpha; Treg: Tegulatory T cell
\end{abstract}

\section{Acknowledgements}

Not applicable

\section{Authors' contributions}

All authors contributed in the planning and writing of this review article. The authors read and approved the final manuscript.

\section{Authors' information}

Authors have multiple decades of experience with oncolytic viruses, cancer immunotherapies, and T cells. $\mathrm{OH}$ is an adjunct professor and a specialist in urology currently working as a uro-oncology fellow in Toronto. AH is the founder of TILT Biotherapeutics and a Professor of Oncology at University of Helsinki. JMS is finalizing his PhD at University of Helsinki Cancer Gene Therapy Group and Head of Cell Therapy at TILT Biotherapeutics.

\section{Funding}

Thus study was supported by Biomedicum Helsinki Foundation, Finska Läkaresällskapet, Jane and Aatos Erkko Foundation, HUCH Research Funds (VTR), Sigrid Juselius Foundation, Finnish Cancer Organizations, University of 
Helsinki, Novo Nordisk Foundation, Päivikki and Sakari Sohlberg Foundation, and The Finnish Society of Sciences and Letters.

\section{Availability of data and materials}

Not applicable

\section{Ethics approval and consent to participate}

Not applicable

\section{Consent for publication}

Not applicable

\section{Competing interests}

$\mathrm{OH}$ and $\mathrm{AH}$ are shareholders in TILT Biotherapeutics Ltd. JMS and AH are employees of TILT Biotherapeutics Ltd, and TILT-123 is a product of this company. $\mathrm{AH}$ and $\mathrm{OH}$ are also shareholders in Targovax ASA, and ONCOS-102 is a product of this company.

\section{Author details}

'Division of Urologic Oncology, Department of Surgical Oncology, Princess Margaret Cancer Centre, University Health Network and University of Toronto, Toronto, Ontario, Canada. ${ }^{2}$ Cancer Gene Therapy Group, Translational Immunology Research Program, University of Helsinki, Helsinki, Finland. ${ }^{3}$ Department of Urology, Helsinki University Hospital, Helsinki, Finland. ${ }^{4}$ TILT Biotherapeutics Ltd, Helsinki, Finland. ${ }^{5}$ Helsinki University Hospital Comprehensive Cancer Center, Helsinki, Finland.

\section{Received: 2 April 2020 Accepted: 17 June 2020}

\section{Published online: 29 June 2020}

\section{References}

1. Lippman SM, Hawk ET. Cancer prevention: from 1727 to milestones of the past 100 years. Cancer Res. 2009;69(13):5269-84.

2. Segovia-Siapco G, Sabate J. Health and sustainability outcomes of vegetarian dietary patterns: a revisit of the EPIC-Oxford and the Adventist Health Study-2 cohorts. Eur J Clin Nutr. 2019;72(Suppl 1):60-70.

3. Bray F, Ferlay J, Soerjomataram I, Siegel RL, Torre LA, Jemal A. Global cancer statistics 2018: GLOBOCAN estimates of incidence and mortality worldwide for 36 cancers in 185 countries. CA Cancer J Clin. 2018;68(6):394-424.

4. Cerullo V, Capasso C, Vaha-Koskela M, Hemminki O, Hemminki A. Cancertargeted oncolytic adenoviruses for modulation of the immune system. Curr Cancer Drug Targets. 2018;18(2):124-38.

5. Hemminki O, Oksanen M, Taipale K, Liikanen I, Koski A, Joensuu T, et al. Oncograms visualize factors influencing long-term survival of cancer patients treated with adenoviral oncolytic immunotherapy. Mol Ther Oncolytics. 2018:9:41-50.

6. Gratwohl A, Baldomero H, Aljurf M, Pasquini MC, Bouzas LF, Yoshimi A, et al. Hematopoietic stem cell transplantation: a global perspective. JAMA. 2010; 303(16):1617-24.

7. Zhang L, Yu H, Hemminki O, Forsti A, Sundquist K, Hemminki K. Familial associations in testicular cancer with other cancers. Sci Rep. 2018;8(1):10880

8. Zhang L, Hemminki O, Chen T, Yu H, Zheng G, Chattopadhyay S, et al. Second cancers and causes of death in patients with testicular cancer in Sweden. PLoS One. 2019;14(3):e0214410.

9. Thorsson V, Gibbs DL, Brown SD, Wolf D, Bortone DS, Ou Yang TH, et al. The immune landscape of cancer. Immunity. 2018;48(4):812-30 e14.

10. Freedman JD, Hagel J, Scott EM, Psallidas I, Gupta A, Spiers L, et al. Oncolytic adenovirus expressing bispecific antibody targets T-cell cytotoxicity in cancer biopsies. EMBO Mol Med. 2017;9(8):1067-87.

11. Vinay DS, Ryan EP, Pawelec G, Talib WH, Stagg J, Elkord E, et al. Immune evasion in cancer: mechanistic basis and therapeutic strategies. Semin Cancer Biol. 2015:35(Suppl):S185-S98.

12. Hanahan D, Weinberg RA. Hallmarks of cancer: the next generation. Cell. 2011;144(5):646-74.

13. Lizee G, Overwijk WW, Radvanyi L, Gao J, Sharma P, Hwu P. Harnessing the power of the immune system to target cancer. Annu Rev Med. 2013;64:71-90.

14. Jessy T. Immunity over inability: The spontaneous regression of cancer. Nat Sci Biol Med. 2011;2(1):43-9.
15. Kucerova P, Cervinkova M. Spontaneous regression of tumour and the role of microbial infection-possibilities for cancer treatment. Anti-Cancer Drugs. 2016;27(4):269-77

16. Coley WB. The treatment of malignant tumors by repeated inoculations of erysipelas. With a report of ten original cases. 1893. Clin Orthop Relat Res. 1991;(262):3-11.

17. Kelly E, Russell SJ. History of oncolytic viruses: genesis to genetic engineering. Mol Ther. 2007;15(4):651-9.

18. Toth K, Wold WS. Increasing the efficacy of oncolytic adenovirus vectors. Viruses. 2010;2(9):1844-66.

19. Huebner RJ, Bell JA, Rowe WP, Ward TG, Suskind RG, Hartley JW, et al. Studies of adenoidal-pharyngeal-conjunctival vaccines in volunteers. J Am Med Assoc. 1955:159(10):986-9.

20. Huebner RJ, Rowe WP, Schatten WE, Smith RR, Thomas LB. Studies on the use of viruses in the treatment of carcinoma of the cervix. Cancer. 1956;9(6): 1211-8.

21. Zielinski T, Jordan E. Remote results of clinical observation of the oncolytic action of adenoviruses on cervix cancer. Nowotwory. 1969;19(3):217-21.

22. Georgiades J, Zielinski T, Cicholska A, Jordan E. Research on the oncolytic effect of APC viruses in cancer of the cervix uteri; preliminary report. Biuletyn Instytutu Medycyny Morskiej w Gdansku. 1959:10:49-57.

23. Bischoff JR, Kirn DH, Williams A, Heise C, Horn S, Muna M, et al. An adenovirus mutant that replicates selectively in p53-deficient human tumor cells. Science. 1996;274(5286):373-6.

24. Andreansky S, Soroceanu L, Flotte ER, Chou J, Markert JM, Gillespie GY, et al. Evaluation of genetically engineered herpes simplex viruses as oncolytic agents for human malignant brain tumors. Cancer Res. 1997;57(8):1502-9.

25. Hemminki O, Hemminki A. A century of oncolysis evolves into oncolytic immunotherapy. Oncoimmunology. 2016;5(2):e1074377.

26. Sun X, Gan L, Na A, Ge L, Chen B, Liu J. Combination with stereotactic body radiotherapy offers a promising strategy to overcome resistance to immunotherapy in advanced renal cell cancer. J Oncol. 2019;2019:1483406.

27. Wu J, Waxman DJ. Immunogenic chemotherapy: dose and schedule dependence and combination with immunotherapy. Cancer Lett. 2018; 419:210-21

28. Salmon H, Remark R, Gnjatic S, Merad M. Host tissue determinants of tumour immunity. Nat Rev Cancer. 2019;19(4):215-27.

29. Kaufman HL, Kohlhapp FJ, Zloza A. Oncolytic viruses: a new class of immunotherapy drugs. Nat Rev Drug Discov. 2015;14(9):642-62

30. Hemminki O, Bauerschmitz G, Hemmi S, Lavilla-Alonso S, Diaconu I, Guse K, et al. Oncolytic adenovirus based on serotype 3. Cancer Gene Ther. 2011; 18(4):288-96.

31. Cerullo V, Diaconu I, Romano V, Hirvinen M, Ugolini M, Escutenaire S, et al. An oncolytic adenovirus enhanced for toll-like receptor 9 stimulation increases antitumor immune responses and tumor clearance. Mol Ther. 2012;20(11):2076-86.

32. Bergelson JM, Cunningham JA, Droguett G, Kurt-Jones EA, Krithivas A, Hong $\mathrm{JS}$, et al. Isolation of a common receptor for Coxsackie B viruses and adenoviruses 2 and 5. Science 1997:275(5304):1320-3.

33. Short JJ, Vasu C, Holterman MJ, Curiel DT, Pereboev A. Members of adenovirus species B utilize CD80 and CD86 as cellular attachment receptors. Virus Res. 2006;122(1-2):144-53.

34. Sirena D, Lilienfeld B, Eisenhut M, Kalin S, Boucke K, Beerli RR, et al. The human membrane cofactor CD46 is a receptor for species $B$ adenovirus serotype 3. J Virol. 2004;78(9):4454-62.

35. Wang H, Li ZY, Liu Y, Persson J, Beyer I, Moller T, et al. Desmoglein 2 is a receptor for adenovirus serotypes 3, 7, 11 and 14. Nat Med. 2011; 17(1):96-104

36. Wickham TJ, Mathias P, Cheresh DA, Nemerow GR. Integrins alpha $v$ beta 3 and alpha $v$ beta 5 promote adenovirus internalization but not virus attachment. Cell. 1993:73(2):309-19.

37. Hemminki O. Cancer Immunotherapy with a Serotype 3 Oncolytic Adenovirus: LAP LAMBERT Academic Publishing; 2016.

38. Cohen CJ, Shieh JT, Pickles RJ, Okegawa T, Hsieh JT, Bergelson JM. The coxsackievirus and adenovirus receptor is a transmembrane component of the tight junction. Proc Natl Acad Sci U S A. 2001;98(26):15191-6.

39. Fleischli C, Sirena D, Lesage G, Havenga MJ, Cattaneo R, Greber UF et al. Species B adenovirus serotypes 3, 7,11 and 35 share similar binding sites on the membrane cofactor protein CD46 receptor. J Gen Virol. 2007:88(Pt 11):2925-34 
40. Wang H, Li Z, Yumul R, Lara S, Hemminki A, Fender P, et al. Multimerization of adenovirus serotype 3 fiber knob domains is required for efficient binding of virus to desmoglein 2 and subsequent opening of epithelial junctions. J Virol. 2011;85(13):6390-402.

41. Lu ZZ, Wang H, Zhang Y, Cao H, Li Z, Fender P, et al. Penton-dodecahedral particles trigger opening of intercellular junctions and facilitate viral spread during adenovirus serotype 3 infection of epithelial cells. PLoS Pathog. 2013; 9(10):e1003718.

42. Arnberg N. Adenovirus receptors: implications for targeting of viral vectors. Trends Pharmacol Sci. 2012;33(8):442-8.

43. Zhang Y, Bergelson JM. Adenovirus receptors. J Virol. 2005;79(19):12125-31.

44. Hong SS, Karayan L, Tournier J, Curiel DT, Boulanger PA. Adenovirus type 5 fiber knob binds to MHC class I alpha2 domain at the surface of human epithelial and B lymphoblastoid cells. EMBO J. 1997;16(9):2294-306.

45. Chu Y, Heistad D, Cybulsky MI, Davidson BL. Vascular cell adhesion molecule-1 augments adenovirus-mediated gene transfer. Arterioscler Thromb Vasc Biol. 2001;21(2):238-42.

46. Smith TA, Idamakanti N, Rollence ML, Marshall-Neff J, Kim J, Mulgrew K, et al. Adenovirus serotype 5 fiber shaft influences in vivo gene transfer in mice. Hum Gene Ther. 2003;14(8):777-87.

47. Balakireva L, Schoehn G, Thouvenin E, Chroboczek J. Binding of adenovirus capsid to dipalmitoyl phosphatidylcholine provides a novel pathway for virus entry. J Virol. 2003;77(8):4858-66.

48. Hemminki O, Immonen R, Narvainen J, Kipar A, Paasonen J, Jokivarsi KT, et al. In vivo magnetic resonance imaging and spectroscopy identifies oncolytic adenovirus responders. Int J Cancer. 2014;134(12):2878-90.

49. Koski A, Karli E, Kipar A, Escutenaire S, Kanerva A, Hemminki A. Mutation of the fiber shaft heparan sulphate binding site of a $5 / 3$ chimeric adenovirus reduces liver tropism. PLoS One. 2013;8(4):e60032.

50. Liikanen I, Monsurro V, Ahtiainen L, Raki M, Hakkarainen T, Diaconu I, et al. Induction of interferon pathways mediates in vivo resistance to oncolytic adenovirus. Mol Ther. 2011;19(10):1858-66.

51. Liikanen I, Koski A, Merisalo-Soikkeli M, Hemminki O, Oksanen M, Kairemo K, et al. Serum HMGB1 is a predictive and prognostic biomarker for oncolytic immunotherapy. Oncoimmunology. 2015;4(3):e989771.

52. Ranki T, Joensuu T, Jager E, Karbach J, Wahle C, Kairemo K, et al. Local treatment of a pleural mesothelioma tumor with ONCOS-102 induces a systemic antitumor CD8+ T-cell response, prominent infiltration of CD8+ lymphocytes and Th1 type polarization. Oncoimmunology. 2014;3(10): e958937.

53. Seder RA, Darrah PA, Roederer M. T-cell quality in memory and protection: implications for vaccine design. Nat Rev Immunol. 2008:8(4):247-58.

54. Leung EYL, Ennis DP, Kennedy PR, Hansell C, Dowson S, Farquharson M, et al. NK cells augment oncolytic adenovirus cytotoxicity in ovarian cancer. Mol Ther Oncolytics. 2020;16:289-301.

55. Massari I, Donnini A, Argentati K, Straino S, Mangoni A, Gaetano C, et al. Age-dependent effects of repeated immunization with a first generation adenovirus vector on the immune response and transgene expression in young and old rats. Exp Gerontol. 2002;37(6):823-31.

56. Kaufman HL, Kohlhapp FJ, Zloza A. Oncolytic viruses: a new class of immunotherapy drugs. Nat Rev Drug Discov. 2016;15(9):660.

57. de Queiroz N, Xia T, Konno H, Barber GN. Ovarian cancer cells commonly exhibit defective STING signaling which affects sensitivity to viral oncolysis. Mol Cancer Res. 2019;17(4):974-86.

58. Jhawar SR, Thandoni A, Bommareddy PK, Hassan S, Kohlhapp FJ, Goyal S, et al. Oncolytic viruses-natural and genetically engineered cancer immunotherapies. Front Oncol. 2017;7:202.

59. Bayo-Puxan N, Gimenez-Alejandre M, Lavilla-Alonso S, Gros A, Cascallo M, Hemminki A, et al. Replacement of adenovirus type 5 fiber shaft heparan sulfate proteoglycan-binding domain with RGD for improved tumor infectivity and targeting. Hum Gene Ther. 2009;20(10):1214-21.

60. Kanerva A, Wang M, Bauerschmitz GJ, Lam JT, Desmond RA, Bhoola SM, et al. Gene transfer to ovarian cancer versus normal tissues with fibermodified adenoviruses. Mol Ther. 2002;5(6):695-704.

61. Lang FF, Conrad C, Gomez-Manzano C, Yung WKA, Sawaya R, Weinberg JS, et al. Phase I Study of DNX-2401 (Delta-24-RGD) oncolytic adenovirus: replication and immunotherapeutic effects in recurrent malignant glioma. J Clin Oncol. 2018;36(14):1419-27.

62. Kanerva A, Mikheeva GV, Krasnykh V, Coolidge CJ, Lam JT, Mahasreshti PJ, et al. Targeting adenovirus to the serotype 3 receptor increases gene transfer efficiency to ovarian cancer cells. Clin Cancer Res. 2002:8(1):275-80.
63. Koski A, Bramante S, Kipar A, Oksanen M, Juhila J, Vassilev L, et al. Biodistribution analysis of oncolytic adenoviruses in patient autopsy samples reveals vascular transduction of noninjected tumors and tissues. Mol Ther. 2015;23(10):1641-52.

64. Hemminki O, Diaconu I, Cerullo V, Pesonen SK, Kanerva A, Joensuu T, et al. Ad3-hTERT-E1A, a fully serotype 3 oncolytic adenovirus, in patients with chemotherapy refractory cancer. Mol Ther. 2012;20(9):1821-30.

65. Kuhn I, Harden P, Bauzon M, Chartier C, Nye J, Thorne S, et al. Directed evolution generates a novel oncolytic virus for the treatment of colon cancer. PLoS One. 2008;3(6):e2409.

66. Kanerva A, Nokisalmi P, Diaconu I, Koski A, Cerullo V, Liikanen I, et al. Antiviral and antitumor T-cell immunity in patients treated with GM-CSFcoding oncolytic adenovirus. Clin Cancer Res. 2013;19(10):2734-44.

67. Bramante S, Koski A, Kipar A, Diaconu I, Liikanen I, Hemminki O, et al. Serotype chimeric oncolytic adenovirus coding for GM-CSF for treatment of sarcoma in rodents and humans. Int J Cancer. 2014;135(3):720-30.

68. Chang J, Zhao X, Wu X, Guo Y, Guo H, Cao J, et al. A Phase I study of KH901, a conditionally replicating granulocyte-macrophage colonystimulating factor: armed oncolytic adenovirus for the treatment of head and neck cancers. Cancer Biol Ther. 2009;8(8):676-82.

69. Wang X, Su C, Cao H, Li K, Chen J, Jiang L, et al. A novel triple-regulated oncolytic adenovirus carrying p53 gene exerts potent antitumor efficacy on common human solid cancers. Mol Cancer Ther. 2008;7(6):1598-603.

70. Xu C, Sun Y, Wang Y, Yan Y, Shi Z, Chen L, et al. CEA promoter-regulated oncolytic adenovirus-mediated Hsp70 expression in immune gene therapy for pancreatic cancer. Cancer Lett. 2012;319(2):154-63.

71. DeWeese TL, van der Poel H, Li S, Mikhak B, Drew R, Goemann M, et al. A phase I trial of CV706, a replication-competent, PSA selective oncolytic adenovirus, for the treatment of locally recurrent prostate cancer following radiation therapy. Cancer Res. 2001;61(20):7464-72

72. Hemminki O, Parviainen S, Juhila J, Turkki R, Linder N, Lundin J, et al. Immunological data from cancer patients treated with Ad5/3-E2F-Delta24GMCSF suggests utility for tumor immunotherapy. Oncotarget. 2015;6(6): 4467-81.

73. Bauerschmitz GJ, Guse K, Kanerva A, Menzel A, Herrmann I, Desmond RA, et al. Triple-targeted oncolytic adenoviruses featuring the cox2 promoter, E1A transcomplementation, and serotype chimerism for enhanced selectivity for ovarian cancer cells. Mol Ther. 2006;14(2):164-74.

74. Barton KN, Paielli D, Zhang Y, Koul S, Brown SL, Lu M, et al. Secondgeneration replication-competent oncolytic adenovirus armed with improved suicide genes and ADP gene demonstrates greater efficacy without increased toxicity. Mol Ther. 2006;13(2):347-56.

75. Boucher PD, Im MM, Freytag SO, Shewach DS. A novel mechanism of synergistic cytotoxicity with 5-fluorocytosine and ganciclovir in double suicide gene therapy. Cancer Res. 2006;66(6):3230-7.

76. Taipale K, Liikanen I, Koski A, Heiskanen R, Kanerva A, Hemminki O, et al. Predictive and prognostic clinical variables in cancer patients treated with adenoviral oncolytic immunotherapy. Mol Ther. 2016;24(7):1323-32.

77. Andtbacka RH, Ross M, Puzanov I, Milhem M, Collichio F, Delman KA, et al Patterns of clinical response with talimogene laherparepvec (T-VEC) in patients with melanoma treated in the OPTiM phase III clinical trial. Ann Surg Oncol. 2016;23(13):4169-77.

78. Zafar S, Parviainen S, Siurala M, Hemminki O, Havunen R, Tahtinen S, et al. Intravenously usable fully serotype 3 oncolytic adenovirus coding for CD40L as an enabler of dendritic cell therapy. Oncoimmunology. 2017;6(2): e1265717.

79. Zafar S, Sorsa S, Siurala M, Hemminki O, Havunen R, Cervera-Carrascon V, et al. CD40L coding oncolytic adenovirus allows long-term survival of humanized mice receiving dendritic cell therapy. Oncoimmunology. 2018; 7(10):e1490856.

80. Rajecki M, Kangasmaki A, Laasonen L, Escutenaire S, Hakkarainen T, Haukka J, et al. Sodium iodide symporter SPECT imaging of a patient treated with oncolytic adenovirus Ad5/3-Delta24-hNIS. Mol Ther. 2011;19(4):629-31.

81. Dias JD, Hemminki O, Diaconu I, Hirvinen M, Bonetti A, Guse K, et al. Targeted cancer immunotherapy with oncolytic adenovirus coding for a fully human monoclonal antibody specific for CTLA-4. Gene Ther. 2012; 19(10):988-98.

82. Oh E, Choi IK, Hong J, Yun CO. Oncolytic adenovirus coexpressing interleukin-12 and decorin overcomes Treg-mediated immunosuppression inducing potent antitumor effects in a weakly immunogenic tumor model. Oncotarget. 2017;8(3):4730-46 
83. Jiang $H$, Shin DH, Nguyen $T$, Fueyo J, Fan X, Henry V, et al. Localized treatment with oncolytic adenovirus Delta-24-RGDOX induces systemic immunity against disseminated subcutaneous and intracranial melanomas. Clin Cancer Res. 2019;25(22):6801-14.

84. Fajardo CA, Guedan S, Rojas LA, Moreno R, Arias-Badia M, de Sostoa J, et al. Oncolytic adenoviral delivery of an EGFR-targeting T-cell engager improves antitumor efficacy. Cancer Res. 2017;77(8):2052-63.

85. Wing A, Fajardo CA, Posey AD Jr, Shaw C, Da T, Young RM, et al. Improving CART-cell therapy of solid tumors with oncolytic virus-driven production of a bispecific T-cell engager. Cancer Immunol Res. 2018;6(5):605-16.

86. Porter CE, Rosewell Shaw A, Jung Y, Yip T, Castro PD, Sandulache VC, et al. Oncolytic adenovirus armed with BiTE, cytokine, and checkpoint inhibitor enables CAR T cells to control the growth of heterogeneous tumors. Mol Ther. 2020.

87. Koski A, Kangasniemi L, Escutenaire S, Pesonen S, Cerullo V, Diaconu I, et al. Treatment of cancer patients with a serotype $5 / 3$ chimeric oncolytic adenovirus expressing GMCSF. Mol Ther. 2010;18(10):1874-84.

88. Kanerva A, Koski A, Liikanen I, Oksanen M, Joensuu T, Hemminki O, et al. Case-control estimation of the impact of oncolytic adenovirus on the survival of patients with refractory solid tumors. Mol Ther. 2015;23(2):321-9.

89. Machiels JP, Salazar R, Rottey S, Duran I, Dirix L, Geboes K, et al. A phase 1 dose escalation study of the oncolytic adenovirus enadenotucirev, administered intravenously to patients with epithelial solid tumors (EVOLVE). J Immunother Cancer. 2019;7(1):20.

90. Kent LN, Leone G. The broken cycle: E2F dysfunction in cancer. Nat Rev Cancer. 2019;19(6):326-38.

91. Shay JW. Role of telomeres and telomerase in aging and cancer. Cancer Discov. 2016;6(6):584-93.

92. Cerullo V, Pesonen S, Diaconu I, Escutenaire S, Arstila PT, Ugolini M, et al. Oncolytic adenovirus coding for granulocyte macrophage colonystimulating factor induces antitumoral immunity in cancer patients. Cancer Res. 2010;70(11):4297-309.

93. Simmons AD, Li B, Gonzalez-Edick M, Lin C, Moskalenko M, Du T, et al. GMCSF-secreting cancer immunotherapies: preclinical analysis of the mechanism of action. Cancer Immunol Immunother. 2007;56(10):1653-65.

94. Ranki T, Pesonen S, Hemminki A, Partanen K, Kairemo K, Alanko T, et al. Phase I study with ONCOS-102 for the treatment of solid tumors - an evaluation of clinical response and exploratory analyses of immune markers. J Immunother Cancer. 2016:4:17.

95. Tahtinen S, Kaikkonen S, Merisalo-Soikkeli M, Gronberg-Vaha-Koskela S, Kanerva A, Parviainen S, et al. Favorable alteration of tumor microenvironment by immunomodulatory cytokines for efficient T-cell therapy in solid tumors. PLoS One. 2015;10(6):e0131242.

96. Eriksson E, Milenova I, Wenthe J, Stahle M, Leja-Jarblad J, Ullenhag G, et al. Shaping the tumor stroma and sparking immune activation by CD40 and 4$1 \mathrm{BB}$ signaling induced by an armed oncolytic virus. Clin Cancer Res. 2017; 23(19):5846-57.

97. Jain RK, Stylianopoulos T. Delivering nanomedicine to solid tumors. Nat Rev Clin Oncol. 2010;7(11):653-64.

98. Pipiya T, Sauthoff H, Huang YQ, Chang B, Cheng J, Heitner S, et al. Hypoxia reduces adenoviral replication in cancer cells by downregulation of viral protein expression. Gene Ther. 2005;12(11):911-7.

99. Cherry T, Longo SL, Tovar-Spinoza Z, Post DE. Second-generation HIFactivated oncolytic adenoviruses with improved replication, oncolytic, and antitumor efficacy. Gene Ther. 2010;17(12):1430-41.

100. Rodriguez-Garcia A, Gimenez-Alejandre M, Rojas JJ, Moreno R, BazanPeregrino M, Cascallo M, et al. Safety and efficacy of VCN-01, an oncolytic adenovirus combining fiber HSG-binding domain replacement with RGD and hyaluronidase expression. Clin Cancer Res. 2015;21(6):1406-18.

101. Niemann J, Woller N, Brooks J, Fleischmann-Mundt B, Martin NT, Kloos A, et al. Molecular retargeting of antibodies converts immune defense against oncolytic viruses into cancer immunotherapy. Nat Commun. 2019;10(1):3236.

102. Fusciello M, Fontana F, Tahtinen S, Capasso C, Feola S, Martins B, et al. Artificially cloaked viral nanovaccine for cancer immunotherapy. Nat Commun. 2019;10(1):5747.

103. Pesonen S, Diaconu I, Cerullo V, Escutenaire S, Raki M, Kangasniemi L, et al. Integrin targeted oncolytic adenoviruses Ad5-D24-RGD and Ad5-RGD-D24 GMCSF for treatment of patients with advanced chemotherapy refractory solid tumors. Int J Cancer. 2012;130(8):1937-47.
104. Nokisalmi P, Pesonen S, Escutenaire S, Sarkioja M, Raki M, Cerullo V, et al Oncolytic adenovirus ICOVIR-7 in patients with advanced and refractory solid tumors. Clin Cancer Res. 2010;16(11):3035-43.

105. Ranki T. Preclinical and clinical evaluation of oncolytic immunotherapy with Ad5/3-E2F1- 2 24-GMCSF (CGTG-602), a GM-CSF producing adenovirus targeted to tumors on four levels ASGCT 2012. Philadelphia; 2012.

106. Taipale K, Liikanen I, Juhila J, Turkki R, Tahtinen S, Kankainen M, et al. Chronic activation of innate immunity correlates with poor prognosis in cancer patients treated with oncolytic adenovirus. Mol Ther. 2016;24(1): 175-83.

107. Liikanen I, Ahtiainen L, Hirvinen ML, Bramante S, Cerullo V, Nokisalmi P, et al Oncolytic adenovirus with temozolomide induces autophagy and antitumor immune responses in cancer patients. Mol Ther. 2013;21(6):1212-23.

108. Koski A, Raki M, Nokisalmi P, Liikanen I, Kangasniemi L, Joensuu T, et al. Verapamil results in increased blood levels of oncolytic adenovirus in treatment of patients with advanced cancer. Mol Ther. 2012;20(1):221-9.

109. Garcia M, Moreno R, Gil-Martin M, Cascallo M, de Olza MO, Cuadra C, et al. A phase 1 trial of oncolytic adenovirus ICOVIR-5 administered intravenously to cutaneous and uveal melanoma patients. Hum Gene Ther. 2019;30(3):352-64.

110. Adair RA, Roulstone V, Scott KJ, Morgan R, Nuovo GJ, Fuller M, et al. Cell carriage, delivery, and selective replication of an oncolytic virus in tumor in patients. Sci Transl Med. 2012;4(138):138ra77.

111. Alberts P, Tilgase A, Rasa A, Bandere K, Venskus D. The advent of oncolytic virotherapy in oncology: the Rigvir(R) story. Eur J Pharmacol. 2018;837:117-26

112. Liang M. Oncorine, the world first oncolytic virus medicine and its update in China. Curr Cancer Drug Targets. 2018;18(2):171-6.

113. Santos JM, Havunen R, Hemminki A. Modulation of the tumor microenvironment with an oncolytic adenovirus for effective T-cell therapy and checkpoint inhibition. Methods Enzymol. 2020;635:205-30.

114. Andtbacka RHI, Collichio F, Harrington KJ, Middleton MR, Downey G, Öhrling K, et al. Final analyses of OPTiM: a randomized phase III trial of talimogene laherparepvec versus granulocyte-macrophage colonystimulating factor in unresectable stage III-IV melanoma. J Immunother Cancer. 2019;7(1):145.

115. Ribas A, Dummer R, Puzanov I, VanderWalde A, Andtbacka RHI, Michielin O, et al. Oncolytic virotherapy promotes intratumoral T cell infiltration and improves anti-PD-1 immunotherapy. Cell. 2018;174(4):1031-2.

116. Chesney J, Puzanov I, Collichio F, Singh P, Milhem MM, Glaspy J, et al. Randomized, open-label phase II study evaluating the efficacy and safety of talimogene laherparepvec in combination with ipilimumab versus ipilimumab alone in patients with advanced, unresectable melanoma. J Clin Oncol. 2018;36(17):1658-67.

117. Hodi FS, Chiarion-Sileni V, Gonzalez R, Grob JJ, Rutkowski P, Cowey CL, et al. Nivolumab plus ipilimumab or nivolumab alone versus ipilimumab alone in advanced melanoma (CheckMate 067): 4-year outcomes of a multicentre, randomised, phase 3 trial. Lancet Oncol. 2018;19(11):1480-92.

118. Bauerschmitz GJ, Kanerva A, Wang M, Herrmann I, Shaw DR, Strong TV, et al. Evaluation of a selectively oncolytic adenovirus for local and systemic treatment of cervical cancer. Int J Cancer. 2004;111(2):303-9.

119. Angelova AL, Witzens-Harig M, Galabov AS, Rommelaere J. The oncolytic virotherapy era in cancer management: prospects of applying $\mathrm{H}-1$ parvovirus to treat blood and solid cancers. Front Oncol. 2017;7:93.

120. Calton CM, Kelly KR, Anwer F, Carew JS, Nawrocki ST. Oncolytic viruses for multiple myeloma therapy. Cancers (Basel). 2018;10(6).

121. Sborov DW, Nuovo GJ, Stiff A, Mace T, Lesinski GB, Benson DM Jr, et al. A phase I trial of single-agent reolysin in patients with relapsed multiple myeloma. Clin Cancer Res. 2014;20(23):5946-55.

122. Dispenzieri A, Tong C, LaPlant B, Lacy MQ, Laumann K, Dingli D, et al. Phase I trial of systemic administration of Edmonston strain of measles virus genetically engineered to express the sodium iodide symporter in patients with recurrent or refractory multiple myeloma. Leukemia. 2017; 31(12):2791-8.

123. Ribas A, Dummer R, Puzanov I, VanderWalde A, Andtbacka RHI, Michielin O, et al. Oncolytic virotherapy promotes intratumoral T cell infiltration and improves anti-PD-1 immunotherapy. Cell. 2017;170(6):1109-19 e10.

124. Sun L, Funchain $P$, Song JM, Rayman P, Tannenbaum C, Ko J, et al. Talimogene laherparepvec combined with anti-PD-1 based immunotherapy for unresectable stage III-IV melanoma: a case series. J Immunother Cancer. 2018;6(1):36. 
125. Chesney J, Puzanov I, Collichio F, Milhem MM, Hauschild A, Chen L, et al. Patterns of response with talimogene laherparepvec in combination with ipilimumab or ipilimumab alone in metastatic unresectable melanoma. Br J Cancer. 2019:121(5):417-20.

126. Kelly CM, Antonescu CR, Bowler T, Munhoz R, Chi P, Dickson MA, et al. Objective response rate among patients with locally advanced or metastatic sarcoma treated with talimogene laherparepvec in combination with pembrolizumab: a phase 2 clinical trial. JAMA Oncol. 2020.

127. Rajecki M, af Hallstrom T, Hakkarainen T, Nokisalmi P, Hautaniemi S, Nieminen $\mathrm{Al}$, et al. Mre11 inhibition by oncolytic adenovirus associates with autophagy and underlies synergy with ionizing radiation. Int J Cancer. 2009; 125(10):2441-9.

128. Havunen R, Siurala M, Sorsa S, Gronberg-Vaha-Koskela S, Behr M, Tahtinen S, et al. Oncolytic adenoviruses armed with tumor necrosis factor alpha and interleukin-2 enable successful adoptive cell therapy. Mol Ther Oncolytics. 2017:4:77-86.

129. Siurala M, Havunen R, Saha D, Lumen D, Airaksinen AJ, Tahtinen S, et al. Adenoviral delivery of tumor necrosis factor-alpha and interleukin-2 enables successful adoptive cell therapy of immunosuppressive melanoma. Mol Ther. 2016;24(8):1435-43.

130. Cervera-Carrascon V, Quixabeira DCA, Havunen R, Santos JM, Kutvonen E, Clubb JHA, et al. Comparison of clinically relevant oncolytic virus platforms for enhancing T-cell therapy of solid tumors. Mol Ther Oncolytics. 2020.

131. Lee S, Margolin K. Cytokines in cancer immunotherapy. Cancers (Basel). 2011;3(4):3856-93.

132. Josephs SF, Ichim TE, Prince SM, Kesari S, Marincola FM, Escobedo AR, et al. Unleashing endogenous TNF-alpha as a cancer immunotherapeutic. J Transl Med. 2018;16(1):242.

133. Jiang T, Zhou C, Ren S. Role of IL-2 in cancer immunotherapy. Oncoimmunology. 2016;5(6):e1163462.

134. Watanabe K, Luo Y, Da T, Guedan S, Ruella M, Scholler J, et al. Pancreatic cancer therapy with combined mesothelin-redirected chimeric antigen receptor T cells and cytokine-armed oncolytic adenoviruses. JCI Insight. 2018;3(7).

135. Santos JM, Cervera-Carrascon V, Havunen R, Zafar S, Siurala M, Sorsa S, et al. Adenovirus Coding for interleukin-2 and tumor necrosis factor alpha replaces lymphodepleting chemotherapy in adoptive T cell therapy. Mo Ther. 2018;26(9):2243-54.

136. Cervera-Carrascon V, Siurala M, Santos JM, Havunen R, Tahtinen S, Karell P, et al. TNFa and IL-2 armed adenoviruses enable complete responses by anti-PD-1 checkpoint blockade. Oncoimmunology. 2018;7(5):e1412902.

\section{Publisher's Note}

Springer Nature remains neutral with regard to jurisdictional claims in published maps and institutional affiliations.

Ready to submit your research? Choose BMC and benefit from:

- fast, convenient online submission

- thorough peer review by experienced researchers in your field

- rapid publication on acceptance

- support for research data, including large and complex data types

- gold Open Access which fosters wider collaboration and increased citations

- maximum visibility for your research: over $100 \mathrm{M}$ website views per year

At $\mathrm{BMC}$, research is always in progress.

Learn more biomedcentral.com/submissions 